\title{
CORPORATE SOCIAL RESPONSIBILITY FROM THE CHINESE PERSPECTIVE
}

\author{
Ying Chen, LL.M.* \\ I. CORPORATE SOCIAL RESPONSIBILITY (CSR) AND SOCIAL PROBLEMS IN \\ CHINA
}

In recent years, several serious incidents causing numerous deaths have garnered special attention from the Chinese Central Government. Coal mines are dangerous in China, and accidents frequently occur throughout the provinces. These accidents, which have resulted in thousands of deaths, have been due to the neglect of safety standards by coal mine owners in favor of economic profit. ${ }^{1}$ Moreover, in September 2008, several large milk and formula companies in China were involved in a notorious product quality scandal known as the "Milk Powder Scandal" or "Infant Formula Scandal." Over 1,200 infants were sickened, hospitalized, and some even died, after being fed formula contaminated with melamine, an industrial chemical that can cause kidney stones and other complications in infants. ${ }^{2}$ Major newspapers in China have also frequently reported social problems such as physical abuse of workers, dangerous working conditions, unfair wages, product quality scandals, and industrial pollution. All of these problems involve a fairly new issue in China: Corporate Social Responsibility (CSR).

It would be inaccurate to say that CSR is a completely new issue in China because the Chinese government has been committed to the improvement of CSR for decades. ${ }^{3}$ The Chinese government seeks to substantially increase social wealth to satisfy social needs; it takes measures to foster job growth; it strives to promote social welfare; and it tries to control pollution to guarantee a better environment. ${ }^{4}$ All such efforts are carried out for the sake of corporate development. ${ }^{5}$ Nevertheless, the term CSR is fairly new in China. The numerous CSR-related laws in China indicate that the government highly values CSR in most aspects of its

* S.J.D. Candidate, Indiana University School of Law-Indianapolis

1. China Coal Mine Blast Death Toll Reaches 92, BBC NEws (Nov. 22, 2009), available at http://news.bbc.co.uk/2/hi/8372760.stm.

2. Jane Macartney \& Sophie Yu, Chinese Milk Powder Contaminated with Melamine Sickens 1,253 Babies, THE TIMES, Sept. 16, 2008, available at http://www.timesonline.co.uk/ tol/news/world/asia/article4758549.ece.

3. Xiaodong Han, Corporate Social Responsibility, An Interview with Liu, Peng, Director of Department of Employers, China Enterprise Confederation (translated by Meifang Xia), BEIJING FORUM (Oct. 10, 2007), http://www.beijingforum.org/en/ ShowArticle.asp?ArticleID $=657$.

4. Id.

5. Id. 
policies related to sustainable economic and social development. However, the lack of enforcement of CSR standards in China has been problematic.

\section{RECOGNITION AND LEGISLATION OF CSR IN CHINA}

\section{A. Chinese Companies' Attitude on CSR}

The concept of CSR in China was vague before 1978. It was not until China adopted certain economic reform policies in $1978^{6}$ that western CSR ideas were introduced. Since then, transnational corporations have been entering the Chinese market. When these corporations cooperate or trade with Chinese companies, some require their Chinese partners to meet their own, established CSR standards. To ensure the implementation of CSR standards, these transnational corporations normally carry out CSR inspections of their Chinese partners. Potential Chinese partners who fail to meet these standards lose the opportunity to do business with these transnational corporations. ${ }^{7}$

Because they are required by their foreign partners to take responsibility for the social and environmental impacts of their business activities, Chinese companies are incentivized to develop CSR awareness. As a result, many Chinese companies have begun to take proactive steps to meet their foreign partners' requirements. ${ }^{8}$ In addition, because of economic reforms, a market economy has gradually replaced the planned economy in China, and many state-owned enterprises have transitioned to private ownership. Under this new socialist market economy, many Chinese companies have become independent legal persons that "feature self-management and profit risks." "They have the legal obligations of CSR and are responsible for the economic, social, and environmental impacts of their activities. Accordingly, CSR awareness is increasingly being developed in many Chinese companies, especially among export-related companies. ${ }^{10}$

\section{B. CSR Legislation in China}

Complementing the increasing awareness of CSR in many Chinese companies, the Chinese government has recognized the importance of

6. See generally Why Is China Growing So Fast?, InTERnATIONAL MONETARY Fund, http://www.imf.org/external/pubs/ft/issues8/ (last visited Jan. 20, 2011).

7. Li-Wen Lin, Note, Corporate Social Accountability Standards in the Global Supply Chain: Resistance, Reconsideration, and Resolution in China, 15 CARDOZO J. INT'L \& COMP. L. 321, 325-26 (2007).

8. Han, supra note 3.

9. Id.

10. Id. 
implementing CSR standards for sustainable economic growth, as evidenced by the incorporation of CSR standards into domestic legislation. " The statutory basis for implementing some CSR standards has already been laid in the Chinese legal system.

\section{The Company Law of the People's Republic of China}

In 1993, when the Company Law of the People's Republic of China (the 1994 Company Law) was first promulgated, the term corporate social responsibility was not explicitly mentioned, but the concept of CSR was indirectly embedded in this law. ${ }^{12}$ Article 14 of the 1994 Company Law required companies to abide by the law, observe professional ethics, strengthen the development of socialist culture and ideology, and subject themselves to supervision by the government and the public. ${ }^{13}$ Furthermore, Articles 15 and 16 emphasized the importance of protecting and promoting workers' rights such as employee skill training, safe production, and the organization of trade unions. ${ }^{14}$ Article 15 articulated each company's responsibility to "protect the legitimate rights and interests of its staff and workers, strengthen labor protection, and ensure safe production"15 and also required each company to "provide its workers with vocational education and in job training in various forms to improve their working quality." Article 16 granted workers the right to "organize a trade union in accordance with the law to carry out trade union activities and protect their legitimate rights and interests" company shall provide the necessary conditions for activities of its trade union." 18

In 2005, the 1994 Company Law was amended. This amended law, effective January 1,2006 , is known as the 2006 Company Law. ${ }^{19}$ In the

11. Eric W. Orts, The Rule of Law in China, 34 VAND. J. TranSNAT'L L. 43, 111 (2001); see also Lin, supra note 7, at 354-55.

12. See generally Zhonghua Renmin Gongheguo Gongsi Fa (中华人民共和国公司法) [Company Law of the People's Republic of China] (promulgated by the Standing Comm. of the Nat'1 People's Cong., Dec. 29, 1993, effective July 1, 1994), available at LAWINFOCHINA,

$\mathrm{http}: / / \mathrm{www}$. lawinfochina.com/law/display.asp?db=1\&id=641\&keyword=company law.

13. Id. art. 14.

14. Id. art. 15,16 .

15. Id. art. 15 .

16. Id.

17. Id. art. 16 .

18. Id.

19. Zhonghua Renmin Gongheguo Gongsi Fa (中华人民共和国公司法) [Company Law of the People's Republic of China] (promulgated by the Standing Comm. of the Nat'l People's Cong., Oct. 27, 2005, effective Jan. 1, 2006), available at LAwINFoChinA http://www.lawinfochina.com/law/display.asp?db=1\&id=4685\&keyword=companylaw [hereinafter 2006 Company Law]. 
2006 Company Law, the term social responsibilities is explicitly articulated, and companies are required to maintain CSR while pursuing economic profit. $^{20}$ Article 5 of the 2006 Company Law states that "[w]hen undertaking business operations, a company shall comply with the laws and administrative regulations, social morality and business morality. It shall act in good faith, accept the supervision of the government and the general public, and bear social responsibilities." ${ }^{21}$ Article 17 strengthens labor rights' protection by obligating companies to enter into formal employment contracts with their employees. ${ }^{22}$ Article 18 specifies trade union and related workers' rights and requires companies to "carry out union activities and safeguard the lawful rights and interests of the employees."23 Each company must also "provide necessary conditions for its labor union to carry out activities." 24 The labor union, on behalf of the employees, must "conclude the collective contract with the company with respect to the remuneration, working hours, welfare, insurance, work safety and sanitation and other matters." 25 The 2006 Company Law lists broad guidelines for doing business in a socially and environmentally responsible manner. More importantly, for the first time, the 2006 Company Law explicitly recognized corporate social responsibility and provided the statutory basis for all companies in China to undertake CSR standards. ${ }^{26}$

\section{The Code of Corporate Governance for Listed Companies in China $(2001)^{27}$}

Following the 1994 Company Law, the China Securities Regulatory Commission and the State Economic and Trade Commission promulgated the Code of Corporate Governance for Listed Companies in China (the Code) in 2001. The Code explicitly emphasizes the importance of companies' social responsibilities and encourages listed companies to incorporate these responsibilities into their everyday business operations. Article 86 of the Code states that "[w]hile maintaining the listed company's development and maximizing the benefits of shareholders, the company shall be concerned with the welfare, environmental protection and public interests of the community in which it resides, and shall pay attention to the

20. Lin, supra note 7, at 359 .

21. 2006 Company Law, supra note 19 art. 5.

22. Id. art. 17 .

23. Id. art.18.

24. Id.

25. Id.

26. Lin, supra note 7, at 359-61.

27. Shangshi Gongsi Zhili Zhunze (上市公司治理准则) [Code of Corporate Governance for Listed Companies in China] (promulgated by the China Securities Regulatory Comm., State Economic and Trade Comm., Jan. 7, 2001), available at http://www.ecgi.org/codes/documents/code_en.pdf. 
company's social responsibilities." ${ }^{28}$ However, the Code applies only to listed companies instead of all companies in general. Also, the Chinese administrative departments instead of the legislature adopted it; therefore, the Code is not generally binding.

\section{The Labor Law of the People's Republic of China (1995) ${ }^{29}$}

The Labor Law of the People's Republic of China (1995) (the Chinese Labor Law) aims to equalize bargaining power between employers and workers. ${ }^{30}$ It provides general rules regarding labor conditions and employment practices, articulates the rights and interests of laborers, ${ }^{31}$ and specifies dispute mechanisms and their working procedures. ${ }^{32}$ The Chinese Labor Law mandates minimum standards for a working age, ${ }^{33}$ labor contracts, ${ }^{34}$ working hours, ${ }^{35}$ fair wages, ${ }^{36}$ labor safety and sanitation, ${ }^{37}$ social insurance, ${ }^{38}$ and other standards for employers to follow. In addition, it grants workers the right to "participate in and organize trade unions in accordance with law[, ${ }^{39}$ and it provides special protection for female and juvenile workers. ${ }^{40}$ This Law is a state law of general binding effect, enabling all workers to claim their rights under the law.

\section{The Trade Union Law of the People's Republic of China (2001) $)^{41}$}

The Trade Union Law of the People's Republic of China (the Chinese Trade Union Law) was promulgated on April 3, 1992, and amended on

28. Id. art. 86 .

29. Zhonghua Renmin Gongheguo Laodong Fa (中华人民共和国劳动法)[Labor Law of the People's Republic of China] (promulgated by the Standing Comm. Nat'l People's Congress, July 5, 1994, effective Jan. 1, 1995), available at LAWINFoCHINA, http://www.lawinfochina.com/law/display.asp?db=1\&id=705\&keyword=The Labor Law of the People's Republic of China.

30. See generally id. art. 17.

31. Id. art. 1.

32. Id. art. $77-84$.

33. Id. art. 15.

34. Id. art. 16-35.

35. Id. art. $36-45$.

36. Id. art. $46-51$.

37. Id. art. 52-57.

38. Id. art. 5, 70-76.

39. Id. art. 7.

40. Id. art. 58-65.

41. Zhonghua Renmin Gongheguo Gonghui Fa (中华人民共和国工会法) [Trade Union Law of the People's Republic of China] (promulgated by the Standing Comm. Nat'l People's Cong., Apr. 3, 1992, amended by the Standing Comm. Nat'l People's Cong., Oct. 27, 2001), available at LAWINFOCHINA, http://www.lawinfochina.com/law/display.asp?db=1\&id= 2088\& keyword=tradeunionlaw [hereinafter Trade Union Law]. 
October 27, 2001. This law builds upon the Chinese Labor Law and defines the goal of trade unions as "[r]epresenting the interests of the employees and protecting the legal rights and interests of the employees.",42 It also grants workers the right to participate in and organize trade unions in accordance with the law "regardless of their nationalities, races, sexes, occupations, religious beliefs or educations. ${ }^{, 43}$ Trade unions, through their leadership, are formed with the goal of protecting employees' rights.

Although the Chinese Trade Union Law explicitly states that it protects workers' rights in the trade unions, it may fail to do so in practice. There is only one organization, the All China Federation of Trade Unions (ACFTU), that can legally represent workers in China. ${ }^{44}$ Thus, all references to a trade union in China are really references to the governmentcontrolled trade union: the ACFTU and its branches. In order to allow unions to better serve workers, the Chinese government must ease its control of trade unions.

\section{The Law of the People's Republic of China on Protection of Consumer Rights and Interests (1994) ${ }^{45}$}

In addition to regulating working conditions and protecting and promoting labor rights, the Chinese government also regulates the external social responsibilities of companies. The rights of consumers are increasingly given importance in China. The Law of the People's Republic of China on Protection of Consumer Rights and Interest (the Chinese Consumer Law), promulgated in 1993, is proof of this. ${ }^{46}$ The Chinese Consumer Law regulates the relationships between consumers and businesses that sell goods or services. It was "formulated for the protection of the legitimate rights and interests of consumers"47 and to ensure fair competition in the marketplace. Product safety and product liability are emphasized in the Chinese Consumer Law. Under this law, business operators are legally responsible for their products and services.

42. Id. art. 2.

43. Id. art. 3.

44. Human Rights Watch, Human Rights and the 2008 Olympics IN BeijngBUSINESS AND LABOR RIGHTS, (Oct. 24, 2008), available at http://www.hrw.org/campaigns/ china/beijing08/labor.htm; see also Nicholas, supra note 6, at 167.

45. Zhonghua Renmin Gongheguo Xiaofeizhe Quanyi Baohu Fa (中华人民共和国消费者权益保护法) [Law of the People's Republic of China on Protection of Consumer Rights and Interests] (promulgated by the Standing Comm. Nat'l People's Cong., Oct. 31, 1993, effective Jan. 1, 1994), available at LAWINFoCHINA, $\mathrm{http}: / / \mathrm{www}$.lawinfochina.com/law/display.asp?db=1\&id=6137\&keyword=consumerrightsan dinterests.

46. See id.

47. Id. art. 1. 
In accordance with the Chinese Consumer Law, if there is a dispute regarding consumer rights and interests, Chinese consumers have several options. They can choose "(1) to consult and conciliate with business operators; (2) to request to consumer associations for mediation; (3) to appeal to relevant administrative departments; (4) to apply to arbitral organs for arbitration according to the arbitral agreements with business operators; [or] (5) to institute legal proceedings in the people's court." ${ }^{, 48}$ The Chinese Consumer Law is a state law of general binding effect. It articulates companies' social responsibilities, provides guidelines for consumers to claim their rights, and promotes a fair environment for all companies.

\section{The Environmental Protection Law of the People's Republic of China $(1989)^{49}$}

Environmental responsibility is one of the most important components of CSR. In addition to taking care of their employees and consumers, business operators are responsible for the impacts their activities have on society and sustainable development, particularly on the environment. The purpose of the Environmental Protection Law of the People's Republic of China (the Chinese Environmental Protection Law) is to protect and improve the environment and to prevent and control pollution, as well as other public health hazards. ${ }^{50}$ The law emphasizes the relationships among environmental protection, human health, and sustainable economic growth. ${ }^{51}$ In general, the Chinese Environmental Protection Law covers environmental concerns of natural resources, ${ }^{52}$ natural ecological systems, ${ }^{53}$ agricultural environment, ${ }^{54}$ marine environment, ${ }^{55}$ and pollution control. ${ }^{56}$

In addition, the Chinese Environmental Protection Law strengthens environmental monitoring. ${ }^{57}$ It also establishes special departments to investigate local environments and make environmental impact assessments, enabling these departments to draw up specific plans for local

48. Id. art. 34 .

49. Zhonghua Renmin Gongheguo Huanjing Baohu Fa (中华人民共和国环境保护法) [Environmental Protection Law of the People's Republic of China] (promulgated by the Standing Comm. Nat'l People's Cong., Dec. 26, 1989, effective Dec. 26, 1989), available at LAWINFOCHINA, http://www.lawinfochina.com/law/display.asp?db=1\&id=1208\&keyword= environmental protection law.

50. Id. art. 1 .

51. Id.

52. Id. art. 7.

53. Id. art. 17, 19 .

54. Id. art. 20.

55. Id. art. 21.

56. Id. art. 10-15.

57. Id. art. 11. 
governments on how to reduce pollution, improve local environments, and promote sustainable development. ${ }^{58}$ More importantly, Chapter IV of the Chinese Environmental Protection Law mandates corporate environmental responsibility regarding pollution control. ${ }^{59}$ Companies are legally obligated to reduce or eliminate pollution and bear liability in accordance with relevant provisions. If a company breaks the law, it is subject to warnings, fines, administrative sanctions, and even criminal responsibility. ${ }^{60}$

\section{Other Laws and Regulations that Promote CSR in China}

There is growing demand in China to develop CSR, and Chinese policymakers appear to recognize this trend. In recent years, the Chinese legislature has passed numerous laws and regulations regarding the improvement of CSR in China. In addition to the laws discussed above, the Product Quality Law of the People's Republic of China (1993), ${ }^{61}$ Food Hygiene Law of the People's Republic of China (1995), ${ }^{62}$ Law of the People's Republic of China on Coal Industry (1996), ${ }^{63}$ Law of the People's Republic of China on Donations for Public Welfare (1999), ${ }^{64}$ Provisions on the Prohibition of Using Child Labor (2002), ${ }^{65}$ Production Safety Law of

58. Id. art. 12.

59. Id. art. 24-34.

60. Id. art. $35-45$.

61. Zhonghua Renmin Gongheguo Chanpin Zhiliang Fa (中华人民共和国产品质量法) [Product Quality Law of the People's Republic of China] (promulgated by Standing Comm. Nat'l People's Cong., Feb. 22, 1993, effective Sept. 1, 1993), available at LAwINFoChINA, $\mathrm{http}: / / \mathrm{www}$. lawinfochina.com/law/display.asp?db=1\&id=1834\&keyword=product quality.

62. Zhonghua Renmin Gongheguo Shipin Weisheng Fa (中华人民共和国食品卫生法) [Food Hygiene Law of the People's Republic of China] (promulgated by Order No. 59 of the President of the People's Republic of China, Oct. 30, 1995, effective Oct. 30, 1995), available at LAWINFOCHINA, http://www.lawinfochina.com/law/display.asp?db=1\&id= $116 \&$ keyword $=$ FoodHygieneLaw.

63. Zhonghua Renmin Gongheguo Meitan Fa (中华人民共和国煤炭法) [Law of the People's Republic of China on the Coal Industry] (promulgated by the Standing Comm. of Nat'l People's Cong., Aug. 29, 1996, effective Dec. 1, 1996), available at LAWINFOCHINA, http://www.lawinfochina.com/law/display.asp?db=1\&id=1034\&key word $=$ coal industry.

64. Zhonghua Renmin Gongheguo Gongyi Shiye Juanzeng Fa (中华人民共和国公益事业捐赠法) [Law of the People's Republic of China on Donations for Public Welfare] (promulgated by Order No. 19 of the President of the People's Republic of China, June 28, 1999, effective Sept. 1, 1999), available at LAwINFoChINA, $\mathrm{http}: / / \mathrm{www}$. lawinfochina.com/law/display.asp?db=1\&id=6238\&keyword=welfare.

65. Jinzhi Shiyong Tonggong Guiding (禁止使用童工规定) [Provisions on the Prohibition of Using Child Labor] (promulgated by Decree No. 364 of the State Council of the People's Republic of China, Oct. 1, 2002, effective Dec. 1, 2002), available at LAWINFOCHINA, http://www.lawinfochina.com/law/display.asp?db=1\&id=2510\&keyword= CHILD. 
the People's Republic of China (2002) ${ }^{66}$ Law of the People's Republic of China on the Prevention and Control of Water Pollution (2008), ${ }^{67}$ Energy Conservation Law of the People's Republic of China (2008), ${ }^{68}$ and Labor Contract Law of the People's Republic of China $(2008)^{69}$ were all promulgated, at least in part, to promote CSR. In particular, after the Milk Powder Scandal in 2008 and the frequent coal mine accidents of recent years, the Food Safety Law of the People's Republic of China (2009) and Measures for the Administration of Contingency Plans for Work Safety Incidents (2009) were passed in order to regulate areas of need in a more detailed manner. ${ }^{70}$ In sum, the Chinese government has been devoted to the improvement of CSR. The promulgation of these laws, regulations, and measures has substantially improved the recognition of CSR standards in China.

66. Zhonghua Renmin Gongheguo Anquan Shengchan Fa
(中华人民共和国安全生产法) [Production Safety Law of the People's Republic of China] (promulgated by Standing Comm. Nat'l People's Cong., June 29, 2002, effective Nov. 1, 2002), available at LAWINFOCHINA, http://www.lawinfochina.com/law/display.asp? $\mathrm{db}=1 \& \mathrm{id}=2387 \&$ keyword=production safety.

67. Zhonghua Renmin Gongheguo Shuiwuran Fangzhi Fa (中华人民共和国水污染防治法) [Law of the People's Republic of China on the Prevention and Control of Water Pollution] (promulgated by the Standing Comm. Nat'l People's Cong., Feb. 28, 2008, effective June 1, 2008), available at LAwINFOCHINA, http://www.lawinfochina.com/law/display.asp?db=1\&id=349\&keyword=water pollution.

68. Zhonghua Renmin Gongheguo Jieyue Nengyuan Fa (中华人民共和国节约能源法) [Energy Conservation Law of the People's Republic of China] (promulgated by the Standing Comm. Nat'l People's Cong., Nov. 1, 1997, and amended by the Standing Comm. Nat'l People's Cong., Oct. 28, 2007, effective Apr. 1, 2008), available at LawINFoCHINA, http://www.lawinfochina.com/law/display.asp?db=1\&id=6467\&keyword=energy.

69. Zhonghua Renmin Gongheguo Laodong Hetong Fa (中华人民共和国劳动合同法) [Labor Contract Law of the People's Republic of China] (promulgated by Order No. 65 of the President of the People's Republic of China, June 29, 2007, effective Jan. 1, 2008), available at LAWINFOCHINA, http://www.lawinfochina.com/law/display.asp? $\mathrm{db}=1 \& \mathrm{id}=6133$ \&keyword=contract.

70. Zhonghua Renmin Gongheguo Shipin Anquan Fa (中华人民共和国食品安全法) [Food Safety Law of the People's Republic of China] (promulgated by Order No. 9 of the President of the People's Republic of China, Feb. 28, 2009, effective June 1, 2009), available at LAwINFOCHINA, http://www.lawinfochina.com/law/display.asp?db=1\&id= 7344\&keyword=Food Safety Law; Shengchan Anquan Shigu Yingji Yu'an Guanli Banfa (生产安全事故应急预案管理办法) [Measures for the Administration of Contingency Plans for Work Safety Incidents] (promulgated by Order No. 17 of the State Administration of Production Safety Supervision and Management, Apr. 1, 2009, effective May 1, 2009), available at LAWINFOCHINA, http://www.lawinfochina.com/law/display.asp?db=1\&id= 7573\&keyword=Measures for the Administration of Contingency Plans for Work Safety Incidents. 


\section{THE IMPROVEMENT OF CSR IN CHINA}

\section{A. Current CSR Standards and Lack of Proper Enforcement}

Chinese companies are aware of the growing concerns regarding $\mathrm{CSR}$, and the Chinese legislature has been incorporating CSR standards into the legal system. ${ }^{71}$ Many Chinese companies, particularly state-owned enterprises and export-oriented companies, are actively implementing CSR standards. ${ }^{72}$ Despite the overall improvement in CSR legislation, problems still exist in practice. Occupational accidents, food-poisoning incidents, and industrial pollution events are frequently in the headlines. ${ }^{73}$ Regrettably, many Chinese companies still focus on profit maximization, and because of this, few of them voluntarily implement CSR principles. ${ }^{74}$ In practice, workers are often required to work much more than forty hours per week and are paid below the minimum wage. ${ }^{75}$ Unsurprisingly, dangerous working conditions, food safety incidents, and excessive industrial pollution remain common. ${ }^{76}$ Even though China has incorporated CSR into its legislation, the continuing frequency of CSR failures results from the lack of proper enforcement. Consequently, further reforms are necessary to make substantial changes for the implementation of CSR standards in China.

\section{B. Recommendations on How to Promote CSR in China's Sustainable Economic Growth}

Despite promulgation of much CSR legislation, in many cases, enforcement in practice differs from the law as it appears on paper. Accordingly, it is important for the Chinese government to take measures to effectively enforce its laws. With respect to the implementation of CSR standards, there are two things that must be done. First, for those CSR standards that have been incorporated into the law, the government must ensure that local governments and officials understand the standards and the importance of their enforcement. Fines, administrative sanctions, imprisonment, and other punishments must be visible consequences to companies to be an effective tool to address CSR performance. ${ }^{77}$ Second,

71. See generally infra section II.B.7.

72. Han, supra note 3.

73. Zijun Li, Lack of Corporate Social Responsibility Behind Recent China Accidents, WORLD WATCH INSTITUTE, (Dec. 12, 2005), http://www.worldwatch.org/node/3859.

74. Id.

75. Han, supra note 3.

76. Dana C. Nicholas, Note, China's Labor Enforcement Crisis: International Intervention and Corporate Social Responsibility, 11 SCHOLAR 155, 170 (2009).

77. Id. at 187. 
the government must encourage Chinese companies to implement standards not yet incorporated into law.

Because of China's specific economic, social, and political situations, several steps need to be taken to effectively enforce CSR standards. First, trade unions have to be reformed to allow more independence from the government. Second, understanding of corporate social accountability standards among workers must expand to achieve the goal of protecting labor rights. Chinese workers must be educated to know their rights so that they can claim these rights and prevent their employers from infringing upon them. Third, consumer awareness of CSR must be widely achieved. Only then can consumers play an important role in supervising companies' activities and their rights be better protected. Fourth, media disclosure and criticism of the failure of CSR in some companies is necessary. This can create a powerful incentive for companies to adopt CSR standards. Finally, to promote sustainable development, the Chinese government must also make a more concerted effort to strengthen environmental protection and reduce industrial pollution.

\section{Reform Trade Unions in China}

China promulgated its Trade Union Law in 1992 and amended it in 2001. Read literally, it entitles workers to the right to participate in and organize trade unions. ${ }^{78}$ Although the law guarantees the right to "participate in and organize trade unions[,]" it does not necessarily mean that workers can do so. In practice, workers are not allowed to independently organize unions without pre-approval from related government departments, and there is essentially only one organization, the ACFTU and its branches, that can represent workers in China. ${ }^{79}$ With just one union representing all workers, there is less ability for workers to demand better labor conditions or meaningfully bargain with their employers.

For trade unions to better serve workers, substantial reforms must be made. Currently, the complete freedom of trade unions may not be easily achievable due to the political situation in China ${ }^{80}$ What can be done at present is the empowerment of the ACFTU to bargain with employers for better working conditions, fair wages, reasonable working hours, and other workers' rights. By doing this, the ACFTU can more effectively work to benefit workers. Ultimately, substantial changes and improvements must be made to successfully protect labor rights. Chinese trade unions must be made into free and independent unions without influence from political

78. Trade Union Law, supra note 41 art. 3.

79. HUMAN RigHTS WATCH, supra note 44.

80. See Nicholas, supra note 76 , at 188. 
authorities and other powerful entities. ${ }^{81}$ Workers have to be enabled to participate in and organize trade unions freely and independently. Only then will Chinese workers be in a position to collectively bargain effectively in hopes of substantially improving labor conditions. ${ }^{82}$

\section{Raise Workers' Awareness of Their Own Rights}

Since implementation, many workers have come to enjoy the benefits of these aforementioned CSR standards. However, most do not truly understand the meaning, the purposes, or the goals of CSR. ${ }^{83}$ Most workers are merely passive recipients of the benefits resulting from CSR standards. Despite the fairly high level of protection Chinese law provides for workers, it will be difficult to achieve success without workers' active participation.

Thus, possibly the best and most efficient way to adequately protect and promote labor rights is to make CSR standards, enforcement procedures, and relevant remedies widely known among workers. ${ }^{84}$ The Chinese government should provide systematic and comprehensive education to workers regarding their rights so that they can know what they can do if their rights are infringed upon by their employers. ${ }^{85}$ To achieve this goal, the government should disseminate information through brochures, posters, media, and any other effective means. ${ }^{86}$

Additionally, the flow of workers among companies and its impact on the implementation of CSR standards is important. Normally, exportoriented companies in China more readily and efficiently implement CSR standards than do domestic-oriented companies because of the CSR requirements established by their foreign partners. The improvement of export-oriented employees' awareness of CSR standards is likely to have a positive effect on workers in domestic-oriented companies because laborers who flow among companies may transmit the awareness of CSR to workers who are not covered by the standards. ${ }^{87}$ In sum, labor conditions can be improved if the Chinese government takes measures to increase workers' awareness of CSR standards and available remedies if their rights are infringed upon. ${ }^{88}$

81. Id.

82. Id.

83. Lin, supra note 7 , at 369 .

84. Nicholas, supra note 71 , at 187.

85. Lin, supra note 7, at 369.

86. Id.

87. Id.

88. Nicholas, supra note 71 , at 190. 


\section{Raise Consumer Awareness in China}

Beyond government guidance, the promotion of CSR standards also needs public support. Consumer pressure calling for further CSR standards could play an important role in prodding Chinese companies to implement such standards. Because there is no apparent demand from Chinese consumers for the implementation of CSR standards, domestic-oriented companies in China are only minimally affected by CSR. This stands in stark contrast to the export-oriented companies that are impacted by their trading partners' CSR obligations.

In the modern world, consumption is not only an individual activity, but also one that may influence the consumption preferences of the whole society. If a company is exposed by a reliable consumer association or the media for violations of the law, abuses of human rights, environmental pollution, or the waste of natural resources, consumers may refuse to buy products or services from them. In this way, companies are compelled to implement CSR standards, or at least follow minimal CSR norms. Currently, although there is no apparent demand from Chinese consumers that companies implement CSR practices, these consumers are increasingly "becoming more rights-oriented." 89 The government should make reasonable efforts to continue this trend so that CSR standards will be substantially incorporated into everyday business operations. ${ }^{90}$

\section{Media Supervision}

The promotion of CSR must be a combined effort. In addition to government guidance and consumer action, the mass media, such as television, radio, newspapers, and the Internet, should be widely used to publicize CSR ideas and highlight the importance of meeting CSR standards. This can lead to close supervision and awareness of CSR-related problems. ${ }^{91}$ The recent exposure of coal mine accidents and the Milk Powder Scandal have fostered increasing public interest in CSR. The media can and should act as a supervisor for the enforcement of CSR standards in business operations. When the media disclose and criticize corporations' failures to meet CSR standards, the public is notified of the inappropriate activities of the company. In many cases, some consumers will respond by boycotting the companies for their failures of social or environmental responsibility. In addition, media supervision of corporate social responsibility attracts more attention from local governments and even the Chinese Central Government. The government is then able to take

89. Han, supra note 3 .

90. Id.

91. Id. 
measures to prevent business activities from harming the society, the people, and the environment.

\section{Strengthen Environmental Protection and Reduce Resource Consumption}

Although China may seem to be a large country with adequate natural resources, China also has the largest population in the world. ${ }^{92}$ China has relatively insufficient land, water, energy, and various natural resources necessary for sustainable development. ${ }^{93}$ Environmental protection is for the benefit of both the natural environment and human beings and has become one of the most important tasks of the Chinese government.

Industrial pollution and the waste of natural resources are two important concerns in CSR. One of the goals of CSR is environmental protection, accomplished by controlling industrial pollution and reducing natural resource consumption as much as possible. ${ }^{94}$ In recent years, the Chinese government has advocated for "clean production and green consumption[,]",95 and Chinese companies are making progress toward protecting the environment and saving resources. Nevertheless, more action is needed to make China a resource-conserving and environmentallyfriendly society.

Once again, the Chinese government plays an important role. The government should take measures to raise society's environmental awareness. More money should be allocated to technological innovation for pollution control and the reduction of resource consumption. In addition to government guidance and assistance, it is also companies' responsibility to protect the environment and reduce resource consumption. To uphold this environmental responsibility, corporations must make sure that the impacts of their activities on the environment are minimal. ${ }^{96}$ They should make strategic plans and carry out measures to minimize energy consumption, reduce industrial pollution, and safely dispose of waste material. ${ }^{97}$

92. CIA World FACTBOOK, CENTRAL INTELligenCE AgENCY, https://www.cia.gov/ library/publications/the-world-factbook/geos/ch.html (follow "People" hyperlink) (last visited Jan. 20, 2011).

93. Han, supra note 3.

94. Id.

95. Id.

96. Best Practices, Corporate Social Responsibility in China, THE US-CHINA BUSINESS CounCIL (2006), http://www.uschina.org/public/documents/2006/10/uscbc-csr-bestpractices.pdf.

97. Han, supra note 3. 


\section{CONCLUSION}

Globalization both forces China to be more integrated into the world economy and grants China more power to affect the world than ever before. On the other hand, globalization means that to increase its global competitiveness, China has to adjust its domestic policies to adapt to global market demands. ${ }^{98}$

Worldwide, and in growing numbers, companies are embracing CSR standards in their business operations, and many transnational corporations require their international partners to meet CSR standards. ${ }^{99}$ Therefore, there is growing demand in China to develop and enforce CSR standards. Despite the progress made by many companies, the implementation of CSR standards in China is still in its early stages for most companies. To comply with the expectations and demands of foreign companies and to maintain and improve Chinese companies' competitiveness in the global market, Chinese companies are encouraged to adopt high levels of social and environmental standards and to actively implement these standards. ${ }^{100}$

The promotion of CSR in China should emphasize the following: first, the improvement of working conditions and the protection of workers' safety and other rights; second, the promotion of product safety and the protection of consumers' rights; and third, the control of industrial pollution and the reduction of resource consumption. ${ }^{101}$ Strengthening sustainable development is necessary to the improvement of Chinese national power and would help promote stable and healthy economic development. CSR standards can also contribute to sustainable economic growth; therefore, it is extremely important for Chinese companies to meet CSR standards in their everyday business operations.

98. Lin, supra note 7, at 353.

99. Li, supra note 68.

100. Nicholas, supra note 6 , at 166 .

101. Han, supra note 3. 
